\title{
28 Research Square \\ The prevalence of type 2 diabetes and prediabetes among armed forces personnel: a systematic review and meta-analysis
}

\section{Mohammad Fathalipour}

Hormozgan University of Medical Sciences

Soheil Hassanipour

Guilan University of Medical Sciences

Mojtaba Sepandi ( $\triangle$ msepandi@bmsu.ac.ir)

Baqiyatallah University of Medical Sciences

Maryam Taghdir

Baqiyatallah University of Medical Sciences

Sepideh Abbaszadeh

Baqiyatallah University of Medical Sciences

Research article

Keywords: Prevalence, Diabetes mellitus, Prediabetes, Military personnel, police officers

Posted Date: May 18th, 2020

DOI: https://doi.org/10.21203/rs.3.rs-28477/v1

License: (c) (7) This work is licensed under a Creative Commons Attribution 4.0 International License. Read Full License 


\section{Abstract \\ Background}

Previous studies of diabetes among armed forces personnel did not assess a comprehensive disease prevalence. We conducted a systematic review and meta-analysis to estimate the prevalence of type 2 diabetes and prediabetes among the military personnel and police officers.

\section{Methods}

We carried out a systematic search on electronic databases from January 2000 to January 2020. Cross-sectional and cohort studies with a report of the prevalence of diabetes, prediabetes, or both were selected. Random- or fixed-effects model, along with subgroup analysis on diabetes or prediabetes as well as the component of armed forces, was carried out to determine the overall prevalence.

\section{Results}

Among 258 citations, 17 studies were entered into the meta-analysis, involving 1559737 individuals. The metaanalysis estimated the prevalence of type 2 diabetes among the police officers $(13.78 \% ; 95 \%$ confidence intervals [CI]: 10.14-17.60) was higher than that of the military personnel (7.32\%; Cl: 4.22-10.42). The overall prevalence of prediabetes among the military personnel and the police officers were $7.41 \%$ (Cl: $3.35-11.48)$ and $6.30 \%(\mathrm{Cl}$ : $5.11-7.49)$, respectively.

\section{Conclusion}

The prevalence of diabetes and prediabetes among armed forces were consistent with global reports among general population. Future investigations are warranted to estimate the exact prevalence of diabetes among this occupational group.

\section{Background}

Diabetes mellitus is a major global health-care challenge. Based on the International Diabetes Federation (IDF) diabetes atlas, 463 million people influenced by diabetes in 2019 worldwide and estimated to be 700 million by 2045 [1]. The expenditure of annual global health on diabetes is approximately USD 760 billion [2]. Diabetes causes a number of micro- and macrovascular complications, as the main reason for morbidity and mortality among patients with diabetes [3]. Furthermore, it significantly affects the life expectancy and quality of patients as well as the development of other diseases [4].

Among risk factors of diabetes, occupation has a crucial role. Nowadays, the relationship between occupational factors and the prevalence of diabetes takes the interest of researchers [5]. Armed forces are at high risk of developing cardiometabolic syndrome because they have unique lifestyles and expose to stressful situations [6]. A body of evidence demonstrated that this occupational group, compared to the general population, had a higher prevalence of metabolic diseases, including diabetes $[7,8]$. Additionally, other occupational characteristics, like 
dietary regimens, atypical physical activity, long work hours, social isolation, and ergonomic problems, have a negative impact on the health conditions of armed forces personnel $[9,10]$. The countries' human development index ( $\mathrm{HDI}$ ) as another remarkable factor impress the quality of life and incidence of many disease among different occupations [11].

The combination of these elements contributes to making negative changes in lifestyle among this occupational group. The results of a cohort study showed that armed forces are more prone to non-communicable diseases, especially at earlier ages, and they die much earlier compared to other groups [12].

This evidence warrants for more comprehensive strategies of monitoring and screening to reduce the prevalence of diabetes and its burden. Therefore, we carried out a systematic review and meta-analysis of relevant studies to improve the understanding and knowledge of the prevalence of type 2 diabetes and prediabetes among different components of armed forces personnel (military personnel and police officers) around various geographical parts of the world.

\section{Methods}

The current study is a systematic review and meta-analysis conducted to estimate the prevalence of prediabetes and diabetes among armed forces personnel in 2020. The study carried out based on Preferred Reporting Items for Systematic Reviews and Meta-Analyses (PRISMA) [13].

\section{Literature Search}

A comprehensive literature search of published studies was conducted using Medline/PubMed, Scopus, Embase, ProQuest, and Web of Knowledge, as well as Google Scholar in January 2020. The medical subject headings (MeSH) keywords included "army", "military", "soldiers", "police", "policemen", "cop", "conscript" "diabetes", "prediabetes", "metabolic syndrome", and "prevalence". The keywords dashboard in title and abstract is represented in supplementary material. All articles list were imported to EndNote X7 (Thomson Reuters, Carlsbad, CA, USA) library and the duplicates were automatically removed. Moreover, the references list of included studies were manually searched to ensure satisfying coverage.

\section{Selection criteria}

The primary screening was performed according to the title and abstract, by two independent researchers (MF and $\mathrm{SH})$. After that, data extraction and quality assessment were done by reading the full-test of the remaining articles. In the case of conflict in any of the secondary stages, the corresponding author (MS) made the final decision.

The primary criterion for including the articles was a report of the "prevalence of diabetes or prediabetes among armed forces". Studies with inappropriate population, estimation of incidence, and non-English language, as well as conference abstracts, poster papers, and editorial, were excluded.

\section{Data extraction}

A spreadsheet was prepared using all targeted statistics. This checklist included the name of the first author, year of publishing, time period, location of study, number of participants, and frequency (with lower and upper $95 \%$ 
confidence intervals) for diabetes and prediabetes.

\section{Quality assessment}

The Joanna Briggs Institute (JBI) checklist was applied in order to evaluate the quality of the studies [14]. This appraisal is aimed to estimate the methodological quality and to assess the possibility of bias in the design, conduct, and analysis of studies. The results of the quality assessment are summarized in supplementary material.

\section{Statistical analysis}

The Cochran test (with a significance level of < 0.1 ) in combination with $\mathrm{I}^{2}$ statistics (with a significance level of > $50 \%)$ was used to the heterogeneity of the studies. Thereafter, the random-effects model with the inverse-variance method was applied in the presence of heterogeneity, and the fixed-effects model was used in the absence of heterogeneity. The subgroup analysis was performed in the case of heterogeneity based on the type of disease (diabetes or pre-diabetes), the component of armed forces personnel (military personnel or police officers), and the countries' HDI. All analyses were conducted using STATA software (version 13).

\section{Additional analysis}

The meta-regression was utilized due to the high level of heterogeneity of the included studies. One of these subgroup analyses was the country's HDI as a relative index of life expectancy and quality as well as literacy and education. The other subgroups consisted of the mean age of participants, sample size, and publication year of study.

\section{Sensitivity analysis}

In order to evaluate the quality and consistency of the findings and to assess the robustness of the obtained results, sensitivity analysis was conducted through deleting each study separately.

\section{Assessing risk of bias}

The publication bias was evaluated using the Egger test [15].

\section{Results}

\section{Results of the search}

The primary stage of searches yielded 258 citations. Additionally, 37 studies also identified through gray literature. After removing duplicates, 92 studies selected to investigate the titles and abstracts, and 70 articles were remained for the full-text review. Of these, 33 studies fulfilled the inclusion criteria. Finally, 17 articles, involving 1559737 individuals, were extracted for the meta-analysis. The reasons for exclusion of 75 papers were irrelevant title $(n=23)$, studies with inappropriate population $(n=19)$, not reporting prevalence of either diabetes or prediabetes $(n=10)$, reporting incidence of either diabetes or prediabetes $(n=2)$, review or meta-analysis study ( $n$ $=4)$, non-English papers $(n=10)$, and editorial, conference abstracts, or poster papers $(n=7)$. The flowchart of the included studies is shown in Fig. 1.

\section{Description of studies}


Base on geographical location of 17 included studies, five studies conducted in India [16-20], two in Iran [21, 22], two in Saudi Arabia [23, 24], two in the USA [25, 26], one in Brazil [27], one in Sweden [28], one in Zambia [29], one in Jordan [30], one in Guinea-Bissau [31], and one in Ethiopia [6]. The basic characteristics of the included studies are shown in Table 1. 
Table 1

Characteristics of the studies included in the review.

\begin{tabular}{|c|c|c|c|c|c|c|c|c|c|c|}
\hline \multirow{2}{*}{\multicolumn{2}{|c|}{$\begin{array}{l}\text { Author, } \\
\text { year }\end{array}$}} & \multirow{2}{*}{$\begin{array}{l}\text { Time } \\
\text { period }\end{array}$} & \multirow{2}{*}{$\begin{array}{l}\text { Study } \\
\text { design }\end{array}$} & \multirow[t]{2}{*}{ Country } & \multirow[t]{2}{*}{ Population } & \multirow[t]{2}{*}{ Sex } & \multirow[t]{2}{*}{ Age } & \multirow{2}{*}{$\begin{array}{l}\text { Sample } \\
\text { size }\end{array}$} & \multicolumn{2}{|c|}{ Prevalence } \\
\hline & & & & & & & & & DM & PDM \\
\hline 1 & $\begin{array}{l}\text { Masih, } \\
2019 \text { [16] }\end{array}$ & $\begin{array}{l}2017 \\
\text { to } \\
2018\end{array}$ & $\begin{array}{l}\text { Cross- } \\
\text { sectional }\end{array}$ & India & $\begin{array}{l}\text { Police } \\
\text { officers }\end{array}$ & Male & $\begin{array}{l}40- \\
60\end{array}$ & 155 & 31.6 & - \\
\hline 2 & $\begin{array}{l}\text { Phiri, } \\
2017 \text { [29] }\end{array}$ & - & $\begin{array}{l}\text { Cross- } \\
\text { sectional }\end{array}$ & Zambia & $\begin{array}{l}\text { Police } \\
\text { officers }\end{array}$ & Both & - & 148 & 9.1 & - \\
\hline 3 & $\begin{array}{l}\text { Lindman, } \\
2017 \text { [31] }\end{array}$ & $\begin{array}{l}2009 \\
\text { to } \\
2010\end{array}$ & $\begin{array}{l}\text { Cohort } \\
\text { study }\end{array}$ & $\begin{array}{l}\text { Guinea- } \\
\text { Bissau }\end{array}$ & $\begin{array}{l}\text { Police } \\
\text { officers }\end{array}$ & Both & $\begin{array}{l}19- \\
83\end{array}$ & 1104 & 4.1 & 4.2 \\
\hline 4 & $\begin{array}{l}\text { Tesfaye, } \\
2016[6]\end{array}$ & $\begin{array}{l}\text { April } \\
\text { to } \\
\text { May } \\
2015\end{array}$ & $\begin{array}{l}\text { Cross- } \\
\text { sectional }\end{array}$ & Ethiopia & $\begin{array}{l}\text { Federal } \\
\text { police } \\
\text { commission }\end{array}$ & Both & $\begin{array}{l}18- \\
55\end{array}$ & 936 & 5.0 & 8.0 \\
\hline 5 & $\begin{array}{l}\text { Moline, } \\
2016 \text { [25] }\end{array}$ & $\begin{array}{l}\text { Mar } \\
2008 \\
\text { to } \\
\text { Jun } \\
2010\end{array}$ & $\begin{array}{l}\text { Cross- } \\
\text { sectional }\end{array}$ & USA & $\begin{array}{l}\text { Law } \\
\text { enforcement } \\
\text { officers }\end{array}$ & Both & $\geq$ & 2497 & 14.0 & - \\
\hline 6 & $\begin{array}{l}\text { Crump, } \\
2016 \text { [28] }\end{array}$ & $\begin{array}{l}1969 \\
\text { to } \\
1979\end{array}$ & $\begin{array}{l}\text { Cohort } \\
\text { study }\end{array}$ & Sweden & $\begin{array}{l}\text { Military } \\
\text { conscripts }\end{array}$ & Male & 18 & 1547478 & 0.8 & - \\
\hline 7 & $\begin{array}{l}\text { Afifi, } \\
2015 \text { [23] }\end{array}$ & $\begin{array}{l}2010 \\
\text { to } \\
2011\end{array}$ & $\begin{array}{l}\text { Cross- } \\
\text { sectional }\end{array}$ & $\begin{array}{l}\text { Saudi } \\
\text { Arabia }\end{array}$ & $\begin{array}{l}\text { Armed force } \\
\text { recruits }\end{array}$ & Male & $\begin{array}{l}40- \\
54\end{array}$ & 117 & 21.4 & - \\
\hline 8 & $\begin{array}{l}\text { Filho, } \\
2014 \text { [27] }\end{array}$ & 2012 & $\begin{array}{l}\text { Cross- } \\
\text { sectional }\end{array}$ & Brazil & $\begin{array}{l}\text { Military } \\
\text { police corps }\end{array}$ & Male & $\begin{array}{l}42- \\
57\end{array}$ & 451 & 10.6 & - \\
\hline 9 & $\begin{array}{l}\text { Yoo, } \\
2013 \text { [26] }\end{array}$ & - & $\begin{array}{l}\text { Cross- } \\
\text { sectional }\end{array}$ & USA & $\begin{array}{l}\text { Law } \\
\text { enforcement } \\
\text { officers }\end{array}$ & Male & $\begin{array}{l}22- \\
60\end{array}$ & 106 & 17.9 & - \\
\hline 10 & $\begin{array}{l}\text { Kumar, } \\
2013 \text { [17] }\end{array}$ & $\begin{array}{l}\text { July } \\
\text { to } \\
\text { Nov } \\
2011\end{array}$ & $\begin{array}{l}\text { Cross- } \\
\text { sectional }\end{array}$ & India & $\begin{array}{l}\text { Police } \\
\text { officers }\end{array}$ & Both & $\begin{array}{l}20- \\
59\end{array}$ & 1817 & 15.0 & 6.8 \\
\hline 11 & $\begin{array}{l}\text { Thayyil, } \\
2012 \text { [18] }\end{array}$ & - & $\begin{array}{l}\text { Cross- } \\
\text { sectional }\end{array}$ & India & $\begin{array}{l}\text { Police } \\
\text { officers }\end{array}$ & Male & $\begin{array}{l}26- \\
58\end{array}$ & 823 & 7.0 & 6.7 \\
\hline 12 & $\begin{array}{l}\text { Khoshdel, } \\
2012 \text { [21] }\end{array}$ & $\begin{array}{l}\text { Sep } \\
2010 \\
\text { to } \\
\text { Dec } \\
2011\end{array}$ & $\begin{array}{l}\text { Cross- } \\
\text { sectional }\end{array}$ & Iran & $\begin{array}{l}\text { Military } \\
\text { Parachutists }\end{array}$ & Male & $\begin{array}{l}20- \\
50\end{array}$ & 96 & 5.2 & 4.2 \\
\hline 13 & $\begin{array}{l}\text { Heydari, } \\
2010[22]\end{array}$ & - & $\begin{array}{l}\text { Cross- } \\
\text { sectional }\end{array}$ & Iran & $\begin{array}{l}\text { Military } \\
\text { personnel }\end{array}$ & Male & $\begin{array}{l}20- \\
54\end{array}$ & 341 & 1.8 & 8.5 \\
\hline
\end{tabular}

DM; diabetes mellitus, PDM; prediabetes. 


\begin{tabular}{|c|c|c|c|c|c|c|c|c|c|c|}
\hline & \multirow{2}{*}{$\begin{array}{l}\text { Author, } \\
\text { year }\end{array}$} & \multirow{2}{*}{$\begin{array}{l}\text { Time } \\
\text { period }\end{array}$} & \multirow{2}{*}{$\begin{array}{l}\text { Study } \\
\text { design }\end{array}$} & \multirow[t]{2}{*}{ Country } & \multirow[t]{2}{*}{ Population } & \multirow[t]{2}{*}{ Sex } & \multirow[t]{2}{*}{ Age } & \multirow{2}{*}{$\begin{array}{l}\text { Sample } \\
\text { size }\end{array}$} & \multicolumn{2}{|c|}{ Prevalence } \\
\hline & & & & & & & & & DM & PDM \\
\hline 14 & $\begin{array}{l}\text { Tharkar, } \\
2008 \text { [19] }\end{array}$ & - & $\begin{array}{l}\text { Cross- } \\
\text { sectional }\end{array}$ & India & $\begin{array}{l}\text { Police } \\
\text { officers }\end{array}$ & Male & $\geq$ & 318 & 32.1 & - \\
\hline 15 & $\begin{array}{l}\text { Kumar, } \\
2008 \text { [20] }\end{array}$ & - & $\begin{array}{l}\text { Cross- } \\
\text { sectional }\end{array}$ & India & $\begin{array}{l}\text { Police } \\
\text { officers }\end{array}$ & Male & $\begin{array}{l}20- \\
60\end{array}$ & 2160 & 11.5 & 6.2 \\
\hline 16 & $\begin{array}{l}\text { Khazale, } \\
2007 \text { [30] }\end{array}$ & $\begin{array}{l}\text { Jan } \\
\text { to } \\
\text { Dec } \\
2006\end{array}$ & $\begin{array}{l}\text { Cohort } \\
\text { study }\end{array}$ & Jordan & $\begin{array}{l}\text { Military } \\
\text { pilots }\end{array}$ & Male & - & 111 & 0.0 & 9.6 \\
\hline 17 & $\begin{array}{l}\text { Al- } \\
\text { Qahtani, } \\
2005 \text { [24] }\end{array}$ & 2004 & $\begin{array}{l}\text { Cross- } \\
\text { sectional }\end{array}$ & $\begin{array}{l}\text { Saudi } \\
\text { Arabia }\end{array}$ & $\begin{array}{l}\text { Military } \\
\text { soldiers }\end{array}$ & Male & $\begin{array}{l}20- \\
60\end{array}$ & 1079 & 9.9 & - \\
\hline
\end{tabular}

\section{Heterogeneity}

Considerable inter-study heterogeneity was observed based on the Cochran test and the $\mathrm{I}^{2}$ index. The results of heterogeneity are expressed in Table 2. 
Table 2

Results of heterogeneity among included studies.

\begin{tabular}{|c|c|c|c|c|c|c|c|}
\hline Variable & Category & $\begin{array}{l}\text { \# of } \\
\text { studies }\end{array}$ & $\begin{array}{l}\text { Q- } \\
\text { value }\end{array}$ & $\begin{array}{l}\text { Df } \\
\text { (Q) }\end{array}$ & $\begin{array}{l}\text { I- } \\
\text { squared }\end{array}$ & $\begin{array}{l}\text { P- } \\
\text { value }\end{array}$ & $\begin{array}{l}\text { Selected } \\
\text { model }\end{array}$ \\
\hline \multicolumn{8}{|l|}{ Diabetes } \\
\hline \multirow[t]{3}{*}{$\begin{array}{l}\text { Military } \\
\text { personnel }\end{array}$} & High HDI & 4 & 30.06 & 3 & 93.3 & $<.001$ & Random-effect \\
\hline & $\begin{array}{l}\text { Very High } \\
\text { HDI }\end{array}$ & 3 & 129.94 & 2 & 98.5 & $\begin{array}{l}< \\
0.001\end{array}$ & Random-effect \\
\hline & Overall & 7 & 181.33 & 6 & 97.2 & $\begin{array}{l}< \\
0.001\end{array}$ & Random-effect \\
\hline \multirow[t]{4}{*}{ Police officers } & Low HDI & 2 & 0.94 & 1 & 0.0 & 0.333 & Fixed-effect \\
\hline & Medium HDI & 6 & 132.86 & 5 & 96.2 & $\begin{array}{l}< \\
0.001\end{array}$ & Random-effect \\
\hline & $\begin{array}{l}\text { Very High } \\
\text { HDI }\end{array}$ & 2 & 1.06 & 1 & 5.7 & 0.303 & Fixed-effect \\
\hline & Overall & 10 & 337.91 & 9 & 97.3 & $\begin{array}{l}< \\
0.001\end{array}$ & Random-effect \\
\hline \multicolumn{8}{|l|}{ Prediabetes } \\
\hline \multirow{2}{*}{$\begin{array}{l}\text { Military } \\
\text { personnel }\end{array}$} & High HDI & 3 & 3.59 & 2 & 44.3 & 0.166 & Fixed-effect \\
\hline & Overall & 3 & 3.59 & 2 & 44.3 & 0.166 & Fixed-effect \\
\hline \multirow[t]{3}{*}{ Police officers } & Low HDI & 2 & 12.55 & 1 & 92.0 & $<.001$ & Random-effect \\
\hline & Medium HDI & 3 & 0.64 & 2 & 0.0 & 0.724 & Fixed-effect \\
\hline & Overall & 5 & 16.40 & 4 & 75.6 & 0.003 & Random-effect \\
\hline
\end{tabular}

\section{Results of the meta-analysis Prevalence of diabetes}

The analysis of pooled data indicated the overall prevalence of diabetes among the military personnel was $7.41 \%$ ( $95 \%$ confidence intervals [Cl]: $3.35-11.48 ; I^{2}=97.2 \%, p<0.001$ ). The results of subgroup analyses showed the very low HDI countries had the highest prevalence of diabetes among the military personnel (9.85\%; $\mathrm{Cl}: 1.50-$ $\left.18.20, I^{2}=97.2 \%, p<0.001\right)$. The prevalence of diabetes among the police officers was $13.87 \%$ (Cl: 10.14-17.60; $\left.\mathrm{I}^{2}=97.3 \%, p<0.001\right)$. The highest prevalence of diabetes among the police officers was observed in countries with moderate HDI (16.83\%; Cl: $\left.11.81-21.85, \mathrm{I}^{2}=96.2 \%, p<0.001\right)$. The results of the meta-analysis of diabetes prevalence among armed forces personnel are demonstrated in Fig. 2.

\section{Prevalence of prediabetes}


The overall prevalence of prediabetes among the military personnel and police officers were $7.32 \%$ (Cl: $4.22-$ $\left.10.42, \mathrm{I}^{2}=44.3 \%, p=0.166\right)$ and $6.30 \%\left(\mathrm{Cl}: 5.11-7.49, \mathrm{I}^{2}=75.6 \%, p=0.003\right)$, respectively. The highest prevalence of prediabetes among the military personnel was observed in countries with medium $\mathrm{HDI}\left(6.50 \%\right.$; Cl: $5.80-7.20, \mathrm{I}^{2}$ $=0.0 \%, p=0.724)$. Figure 3 demonstrated the results of prediabetes prevalence among armed forces personnel. The prevalence of diabetes and prediabetes among armed forces personnel are compared in countries in Fig. 4.

\section{Results of the meta-regression}

The Results of meta-regression demonstrated a significant association between publication year of study and the prevalence of diabetes among military personnel (Reg Coef $=0.056, p=0.047$ ). However, this was not significantly associated with HDI score (Reg Coef $=-8.61, p=0.388$ ), sample size (Reg Coef $=0.000, p=0.953)$, and mean age of the participants (Reg Coef $=0.014, p=0.912$ ).

On the other hand, the obtained results showed a significant association between the mean age of the participants and the prevalence of diabetes among police officers. (Reg Coef $=0.067, p=0.041$ ). Such a meaningful finding was not observed for HDI score (Reg Coef $=2.39, p=0.122)$, sample size (Reg Coef $=-0.000, p$ $=0.544$ ), and publication year of study (Reg Coef $=-0.001, p=0.989$ ). The overall results of meta-regression for the prevalence of diabetes are shown in Fig. 5 and Fig. 6 among military personnel and police officers, respectively.

\section{Sensitivity analysis}

The findings were reanalyzed by deleting each study separately. The results were yielded regarding all outcomes (Table 3). 
Table 3

The results of sensitivity analysis.

\begin{tabular}{|c|c|c|c|}
\hline Omitted study & Prevalence (95\% Cl) & Omitted study & Prevalence (95\% Cl) \\
\hline \multicolumn{2}{|c|}{ DM in military personnel } & \multicolumn{2}{|c|}{ DM in police officer } \\
\hline Crump, 2016 & $9.11(3.97-14.25)$ & Masih, 2019 & $12.33(8.63-16.03)$ \\
\hline Afifi, 2015 & $5.56(1.55-9.58)$ & Phiri, 2017 & $14.39(10.43-18.35)$ \\
\hline Filho, 2014 & $6.62(2.46-10.78)$ & Lindman, 2017 & $15.02(11.22-18.81)$ \\
\hline Khoshdel, 2012 & $7.84(3.35-12.34)$ & Tesfaye, 2016 & $15.01(10.94-19.08)$ \\
\hline Heydari, 2010 & $9.05(2.91-15.19)$ & Moline, 2016 & $13.90(9.84-17.96)$ \\
\hline Khazale, 2007 & 7.41 (3.35-11.48) & Yoo, 2013 & $13.53(9.65-17.40)$ \\
\hline Al-Qahtani, 2005 & $6.46(2.78-10.15)$ & Kumar, 2013 & $13.73(9.78-17.68)$ \\
\hline \multirow[t]{4}{*}{ Combined } & $7.41(3.35-11.48)$ & Thayyil, 2012 & $14.79(10.62-18.96)$ \\
\hline & & Tharkar, 2008 & 11.88 (8.37-18.38) \\
\hline & & Kumar, 2008 & $14.30(9.97-18.64)$ \\
\hline & & Combined & $13.87(10.14-17.40)$ \\
\hline \multicolumn{2}{|c|}{ PDM in military personnel } & \multicolumn{2}{|c|}{ PDM in police officer } \\
\hline Khoshdel, 2012 & $8.75(6.14-11.35)$ & Lindman, 2017 & $6.72(6.05-7.38)$ \\
\hline Heydari, 2010 & $6.56(1.31-11.81)$ & Tesfaye, 2016 & $5.94(4.74-7.15)$ \\
\hline Khazale, 2007 & $6.57(2.38-10.76)$ & Kumar, 2013 & $6.18(4.67-7.69)$ \\
\hline \multirow[t]{3}{*}{ Combined } & $7.32(4.22-10.42)$ & Thayyil, 2012 & $6.23(4.80-7.65)$ \\
\hline & & Kumar, 2008 & $6.36(4.71-8.01)$ \\
\hline & & Combined & $6.30(5.11-7.49)$ \\
\hline
\end{tabular}

\section{Publication bias}

Results of Egger's tests demonstrated a lack of publication bias $(p>0.05)$.

\section{Discussion}

To the best of authors' knowledge, this is the first meta-analysis conducted on the prevalence of diabetes and prediabetes among armed forces personnel. Several investigations have reported the prevalence of diabetes and prediabetes among different components of armed forces. However, the result of these studies has demonstrated a range of variability in the prevalence. The reported prevalence of diabetes in armed forces was varied from $0.0-$ $32.1 \%$ or even higher, depending on different diagnostic criteria, age, HDI of countries, special diet, and other 
environmental factors. The present meta-analysis also indicated that different types of armed forces might play a significant role in the prevalence of dysglycemia.

The obtained results demonstrated that the prevalence of diabetes among the military personnel (7.41\%) is lower compare to that of the police officers (13.87\%). The highest reported prevalence of diabetes was also related to studies carried out among police officers $[16,19]$. The overall prevalence of diabetes among military personnel, not police officers, is under the global prevalence of diabetes (9.30\%) [32]. This prevalence is uneven since policemen are expected to be in good shape with regular physical activities. Several previous studies conducted among police officers demonstrated the high prevalence of overweight and obesity made them susceptible to diabetes and heart disease $[33,34]$. These risk factors of dysglycemia also were associated with a mean age of study population, and elderly participants were more prone to develop diabetes [34]. These were consistent with the results of meta-regression among police officers.

The most frequent and highly rated stressors might be the other main reasons for the high prevalence of many mental and non-communicable diseases in this occupation group [35, 36]. Moreover, ergonomic problems, long work hours, and particular nutrition regimen should not be underestimated $[37,38]$. Recent comprehensive studies also showed the prevalence of metabolic syndrome, and its component is high among policemen relative to the general population $[9,19]$.

However, the overall prevalence of diabetes among military personnel is lower than that of other components of armed forces. Several studies reported that diabetes only affected less than two percent of this occupational group $[22,28,30]$. In addition to a more appropriate lifestyle, there are some other factors contributing to the low prevalence of diabetes in the military unit. Men are initially recruited at younger ages and undergo regular medical checkups, physical training, and calorie-controlled diets. Then, those individuals with underlying medical conditions, including central obesity, are exempted from these services or replaced in public services $[9,39]$. Hence, some included military personnel in the present investigation might have a better health-related quality of life compared to the police officers or the general population [39].

The results also showed that the prevalence of diabetes among this population is associated with the year of study. There are several other studies that indicated the prevalence of diabetes is increasing, passing the time [40, 41]. These are not only related to the increasing trend of physical inactivity and consumption of unhealthy diet but also progression in diagnostic techniques as well as effective strategies for detection and follow-up people with dysglycemia [42].

Our findings demonstrated that the prevalence of prediabetes among the military personnel and the police officers were $7.32 \%$ and $6.30 \%$, respectively. A body of evidence has demonstrated a range of prevalence of dysglycemia in armed forces according to different biochemical criteria. Some studies reported a prevalence of impaired fasting glucose about 30-40\%, particularly among police officers [16, 19, 27, 43-45]. However, the overall prevalence of prediabetes in included studies is under the estimated prevalence of the adult population (7.30\%) around the world [46]. However, the fasting blood glucose should be screened regularly among armed forces personnel, as an affordable and invaluable biochemical factor, and impaired fasting glucose would be better to consider as a critical index for early detection and prevention of at-risk population.

\section{Strengths And Limitations}


The main strength of the current study is that this is the first analysis that showed the prevalence of diabetes and prediabetes among armed forces personnel. This study can supply reliable baseline information and may guide other scholars to design and conduct novel researches.

However, several limitations reflected by some factors of data are confirmed. Sufficient information was not available to conduct separate or subgroup analyses in terms of assessment of all age groups. The lack of data regarding lifestyle, physical activity, and nutritional habits of the participants, which could explain the estimated high prevalence of police officers, is another main limitation. Because of the high level of heterogeneity of the included studies, it was only attempted to analyze the results according to countries' HDI.

\section{Conclusion}

In summary, this meta-analysis clearly demonstrated that the prevalence of diabetes and prediabetes among all types of armed forces personnel were consistent with global reports of these diseases among general population. However, the prevalence of diabetes among police officers was relatively high (13.87\%). This high prevalence should be considered as a serious alarm. Future large-scale investigations studying the prevalence of diabetes and its associated factors among armed forces personnel would explain the high estimated prevalence of dysglycemia among police officers, and help to take effective strategies in prevention, early detection and management of diabetes among this occupational group.

\section{Abbreviations}

$\mathrm{Cl}: 95 \%$ confidence interval; IDF:International Diabetes Federation; HDI:human development index; PRISMA:Preferred Reporting Items for Systematic Reviews and Meta-Analyses; MeSH:medical subject headings; JBI:Joanna Briggs Institute.

\section{Declarations}

\section{Ethics approval and consent to participate}

Not applicable.

\section{Consent for publication}

Not applicable.

\section{Availability of data and materials}

All data is presented within the manuscript file.

\section{Competing interests}

The authors declare that they have no competing interests. 


\section{Funding}

Not applicable.

\section{Authors' contributions}

All authors were responsible for conceiving and designing the protocol. MF, SH, and MS designed the study. MF and $\mathrm{MT}$ did the literature search and, together with $\mathrm{SH}$, selected the studies, extracted the relevant data. $\mathrm{SH}$ and MS synthesized the data. MF wrote the first draft of the Manuscript. MS and SA provided critical guidance on the analysis and overall direction of the study. All authors critically revised successive drafts of the paper and approved the final version.

\section{Acknowledgements}

Thanks Dr. Maryam Saleh for the invaluable comments on the study and for editing the final draft.

\section{References}

1. Sinclair A, Saeedi P, Kaundal A, Karuranga S, Malanda B, Williams R. Diabetes and global ageing among 6599-year-old adults: Findings from the International Diabetes Federation Diabetes Atlas, 9(th) edition. Diabetes Res Clin Pract. 2020;138(1):108078. https://doi.org/10.1016/j.diabres.2020.108078.

2. Williams R, Karuranga S, Malanda B, Saeedi P, Basit A, Besancon S, Bommer C, Esteghamati A, Ogurtsova K, Zhang $\mathrm{P}$, et al: Global and regional estimates and projections of diabetes-related health expenditure: Results from the International Diabetes Federation Diabetes Atlas, 9th edition. Diabetes Res Clin Pract. 2020; 138(1):108072. https://doi.org/10.1016/j.diabres.2020.108072.

3. Seghieri G, Policardo L, Anichini R, Franconi F, Campesi I, Cherchi S, Tonolo G. The Effect of Sex and Gender on Diabetic Complications. Curr Diabetes Rev. 2017;13(2):148-60. https://doi.org/10.2174/1573399812666160517115756.

4. Maffi P, Secchi A. The Burden of Diabetes: Emerging Data. Dev Ophthalmol. 2017;60(1):1-5. https://doi.org/10.1159/000459641.

5. Heden Stahl C, Novak M, Hansson PO, Lappas G, Wilhelmsen L, Rosengren A. Incidence of Type 2 diabetes among occupational classes in Sweden: a 35-year follow-up cohort study in middle-aged men. Diabetic medicine: a journal of the British Diabetic Association. 2014;31(6):674-80. https://doi.org/10.1111/dme.12405.

6. Tesfaye T, Shikur B, Shimels T, Firdu N. Prevalence and factors associated with diabetes mellitus and impaired fasting glucose level among members of federal police commission residing in Addis Ababa, Ethiopia. BMC Endocr Disord. 2016;16(1):68. https://doi.org/10.1186/s12902-016-0150-6.

7. Ramakrishnan J, Majgi S, Premarajan K, Lakshminarayanan S, Thangaraj S, Chinnakali P. High prevalence of cardiovascular risk factors among policemen in Puducherry, South India. J Cardiovasc Dis Res. 2013;4(2):112-5.

8. Madhusudhana M, Manjunath ML, Girish BM. A study of distribution and determinants of diabetes mellitus among army personnel in Belgaum Cantonment in India. IJBAR. 2011;2(09):310-6. 
9. Rostami H, Tavakoli HR, Rahimi MH, Mohammadi M. Metabolic Syndrome Prevalence among Armed Forces Personnel (Military Personnel and Police Officers): A Systematic Review and Meta-Analysis. Mil Med. 2019;184(9-10):e417-25.

10. Salimi Y, Taghdir M, Sepandi M, Karimi AA. The prevalence of overweight and obesity among Iranian military personnel: a systematic review and meta-analysis. BMC public health. 2019;19(1):162.

11. Programme UND: Human development indices and indicators: 2018 statistical update. In.: United Nations Development Programme New York, NY; 2018.

12. Wirth M, Vena JE, Smith EK, Bauer SE, Violanti J, Burch J. The epidemiology of cancer among police officers. Am J Ind Med. 2013;56(4):439-53.

13. Moher D, Liberati A, Tetzlaff J, Altman DG, The PRISMA Group. Preferred Reporting Items for Systematic Reviews and Meta-Analyses: The PRISMA Statement. PLoS Med. 2009;6(7):e1000097. doi:10.1371/journal.pmed1000097.

14. Porritt K, Gomersall J, Lockwood C. JBI's Systematic Reviews: Study selection and critical appraisal. Am J Nurs. 2014;114(6):47-52. https://doi.org/10.1097/01.NAJ.0000450430.97383.64.

15. Lin L, Chu H. Quantifying publication bias in meta-analysis. Biometrics. 2018;74(3):785-94.

16. Masih R, Pradesh H, Kaur S, Gupta N, Kaur N, Singh D. The metabolic syndrome: Its prevalence and risk factors among policemen of Patiala, Punjab. Blood Pressure. 2019;130(1):85.

17. Kumar P, Mallik D, Mukhopadhyay DK, Sinhababu A, Mahapatra BS, Chakrabarti P. Prevalence of diabetes mellitus, impaired fasting glucose, impaired glucose tolerance, and its correlates among police personnel in Bankura District of West Bengal. Indian J Public Health. 2013;57(1):24-8. https://doi.org/10.4103/0019557x.111364.

18. Thayyil J, Jayakrishnan TT, Raja M, Cherumanalil JM. Metabolic syndrome and other cardiovascular risk factors among police officers. N Am J Med Sci. 2012;4(12):630-5. https://doi.org/10.4103/1947-

2714.104313.

19. Tharkar S, Kumpatla S, Muthukumaran P, Viswanathan V. High prevalence of metabolic syndrome and cardiovascular risk among police personnel compared to general population in India. J Assoc Physicians India. 2008;56(1):845-9.

20. Kumar S, Mukherjee S, Mukhopadhyay P, Pandit K, Raychaudhuri M, Sengupta N, Ghosh S, Sarkar S, Mukherjee S, Chowdhury S. Prevalence of diabetes and impaired fasting glucose in a selected population with special reference to influence of family history and anthropometric measurements-the Kolkata policeman study. J Assoc Physicians India. 2008;56(1):841-4.

21. Khoshdel A, Jafari SM, Heydari ST, Abtahi F, Ardekani A, Lak FJ. The prevalence of cardiovascular disease risk factors, and metabolic syndrome among iranian military parachutists. Int Cardiovasc Res J. 2012;6(2):51-5.

22. Heydari ST, Khoshdel A, Sabayan B, Abtahi F, Zamirian M, Sedaghat S. Prevalence of cardiovascular risk factors among military personnel in southern Iran. Age (Years). 2010;30(98):29.21.

23. Afifi RM, Omar SR, El Raggal AA. A community screening plan for the prevalence of some chronic diseases in specified adult populations in Saudi Arabia: 1-prediabetes and diabetes mellitus. Int J Diabetes Dev Ctries. 2015;35(3):149-56.

24. Al-Qahtani DA, Imtiaz ML. Prevalence of metabolic syndrome in Saudi adult soldiers. Saudi Med J. 2005;26(9):1360-6. 
25. Moline JM, McLaughlin MA, Sawit ST, Maceda C, Croft LB, Goldman ME, Garcia MJ, lyengar RL, Woodward M. The prevalence of metabolic syndrome among law enforcement officers who responded to the 9/11 World Trade Center attacks. Am J Ind Med. 2016;59(9):752-60. https://doi.org/10.1002/ajim.22649.

26. Yoo H, Franke WD. Sleep habits, mental health, and the metabolic syndrome in law enforcement officers. J Occup Environ Med. 2013;55(1):99-103. https://doi.org/10.1097/JOM.0b013e31826e294c.

27. Filho RT, D'Oliveira A Jr. The Prevalence of Metabolic Syndrome Among Soldiers of the Military Police of Bahia State, Brazil. Am J Mens Health. 2014;8(4):310-5. https://doi.org/10.1177/1557988313510928.

28. Crump C, Sundquist J, Winkleby MA, Sieh W, Sundquist K. Physical Fitness Among Swedish Military Conscripts and Long-Term Risk for Type 2 Diabetes Mellitus: A Cohort Study. Ann Intern Med. 2016;164(9):577-84. https://doi.org/10.7326/M15-2002.

29. Phiri M, Mulenga D, Mazaba ML, Siziya S. Prevalence of Diabetes mellitus and association between knowledge of diabetes and Diabetes mellitus among police officers in Peter Singogo camp, Zambia. Asian Pac J Health Sci. 2017;3(3):87-9.

30. Khazale NS, Haddad F. Prevalence and characteristics of metabolic syndrome in 111 Royal Jordanian Air Force pilots. Aviat Space Environ Med. 2007;78(10):968-72. https://doi.org/10.3357/asem.2097.2007.

31. Lindman J, Strom K, Biague A, Da Silva ZJ, Jakobsson K, Norrgren H, Mansson F, grp SC. Diabetes and prediabetes among police officers in Guinea-Bissau. AJDM. 2017;25(2):19-20.

32. Cho NH, Shaw JE, Karuranga S, Huang Y, da Rocha Fernandes JD, Ohlrogge AW, Malanda B. IDF Diabetes Atlas: Global estimates of diabetes prevalence for 2017 and projections for 2045. Diabetes Res Clin Pract. 2018;138(1):271-81. https://doi.org/10.1016/j.diabres.2018.02.023.

33. Alghamdi AS, Yahya MA, Alshammari GM, Osman MA. Prevalence of overweight and obesity among police officers in Riyadh City and risk factors for cardiovascular disease. Lipids in health disease. 2017;16(1):79. https://doi.org/10.1186/s12944-017-0467-9.

34. Arredondo GP. Body mass index in a group of security forces (policemen). Cross-sectional study. New Insights in Obesity: Genetics Beyond. 2017;12(1):1124-31.

35. Violanti JM, Fekedulegn D, Hartley TA, Charles LE, Andrew ME, Ma CC, Burchfiel CM. Highly Rated and most Frequent Stressors among Police Officers: Gender Differences. American journal of criminal justice: AJCJ. 2016;41(4):645-62. https://doi.org/10.1007/s12103-016-9342-X.

36. Violanti JM, Charles LE, McCanlies E, Hartley TA, Baughman P, Andrew ME, Fekedulegn D, Ma CC, Mnatsakanova A, Burchfiel CM. Police stressors and health: a state-of-the-art review. Policing (Bradford England). 2017;40(4):642-56. https://doi.org/10.1108/PIJPSM-06-2016-0097.

37. Vila B, Morrison GB, Kenney DJ. Improving shift schedule and work-hour policies and practices to increase police officer performance, health, and safety. Police Q. 2002;5(1):4-24.

38. Gibson R, Eriksen R, Lamb K, McMeel Y, Vergnaud AC, Spear J, Aresu M, Chan Q, Elliott P, Frost G. Dietary assessment of British police force employees: a description of diet record coding procedures and crosssectional evaluation of dietary energy intake reporting (The Airwave Health Monitoring Study). BMJ open. 2017;7(4):e012927. https://doi.org/10.1136/bmjopen-2016-012927.

39. Barrett DH, Boehmer TK, Boothe VL, Flanders WD, Barrett DH. Health-related quality of life of U.S. military personnel: a population-based study. Mil Med. 2003;168(11):941-7.

40. Pereira M, Carreira H, Lunet N, Azevedo A. Trends in prevalence of diabetes mellitus and mean fasting glucose in Portugal (1987-2009): a systematic review. Public Health. 2014;128(3):214-21.

Page 15/21 
https://doi.org/10.1016/j.puhe.2013.12.009.

41. Telo GH, Cureau FV, de Souza MS, Andrade TS, Copes F, Schaan BD. Prevalence of diabetes in Brazil over time: a systematic review with meta-analysis. Diabetol Metab Syndr. 2016;8(1):65.

https://doi.org/10.1186/s13098-016-0181-1.

42. Lee B, Lee JS, Lee YW, Jang MA, Song J, Kim JH, Lee WG, Min WK, Lee J, Lee YK. Effect of the Standardization of Diagnostic Tests on the Prevalence of Diabetes Mellitus and Impaired Fasting Glucose. Journal of Korean medical science. 2018;33(10):e81. https://doi.org/10.3346/jkms.2018.33.e81.

43. Lestrina D, Sihotang U, Siahaan G. Obesity with metabolic syndrome to police in Polres Deli Serdang. Int J Pharm Technol. 2016;8(3):15109-23.

44. Hartley TA, Knox SS, Fekedulegn D, Barbosa-Leiker C, Violanti JM, Andrew ME, Burchfiel CM: Association between depressive symptoms and metabolic syndrome in police officers: results from two cross-sectional studies. J Environ Public Health. 2012; 2012(1):861219. https://doi.org/10.1155/2012/861219.

45. Violanti JM, Fekedulegn D, Hartley TA, Andrew ME, Charles LE, Mnatsakanova A, Burchfiel CM. Police trauma and cardiovascular disease: association between PTSD symptoms and metabolic syndrome. Int J Emerg Ment Health. 2006;8(4):227-37.

46. Hostalek U. Global epidemiology of prediabetes - present and future perspectives. Clinical diabetes endocrinology. 2019;5(1):5. https://doi.org/10.1186/s40842-019-0080-0.

\section{Figures}




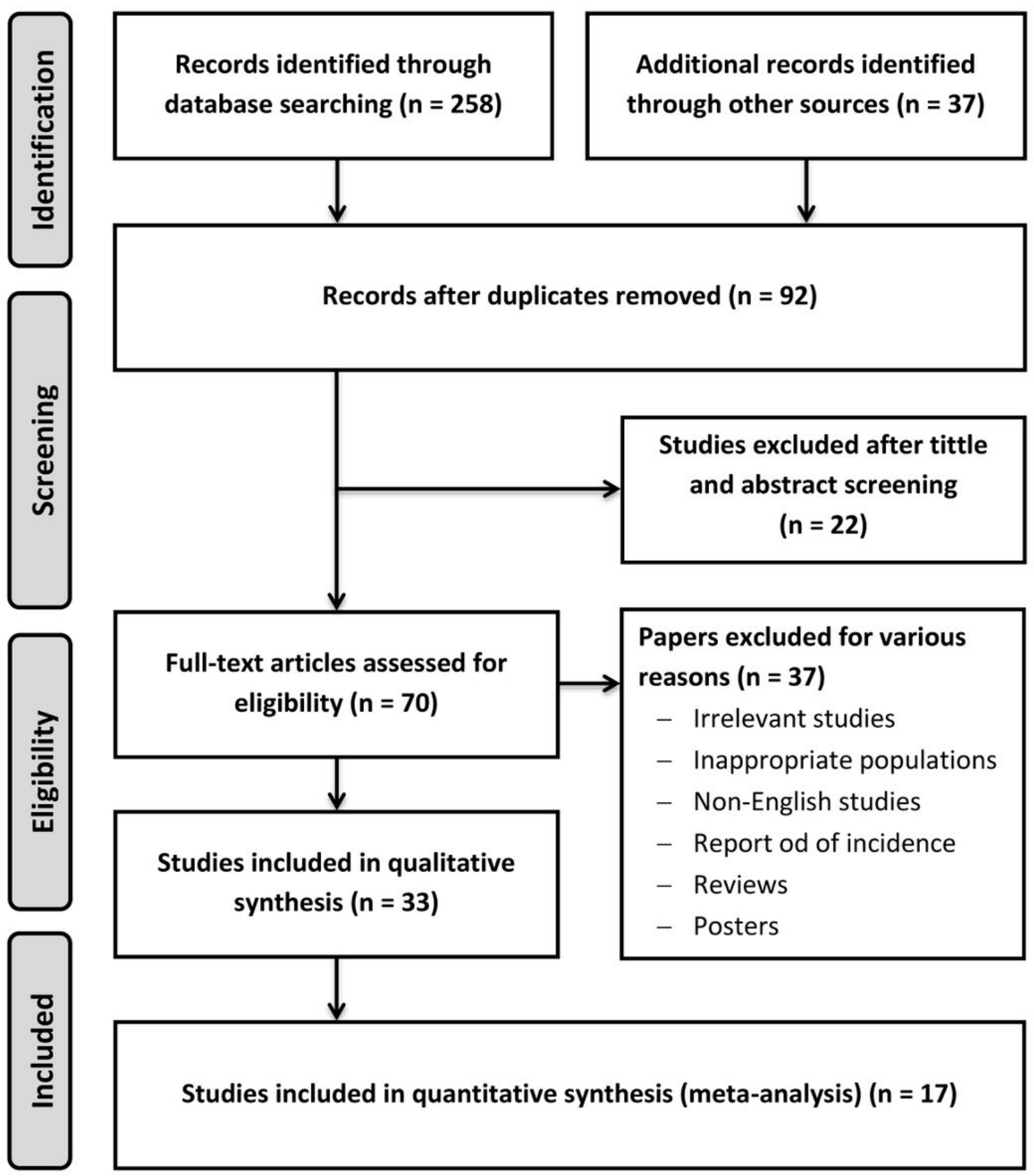

Figure 1

Flowchart of the included studies 
A

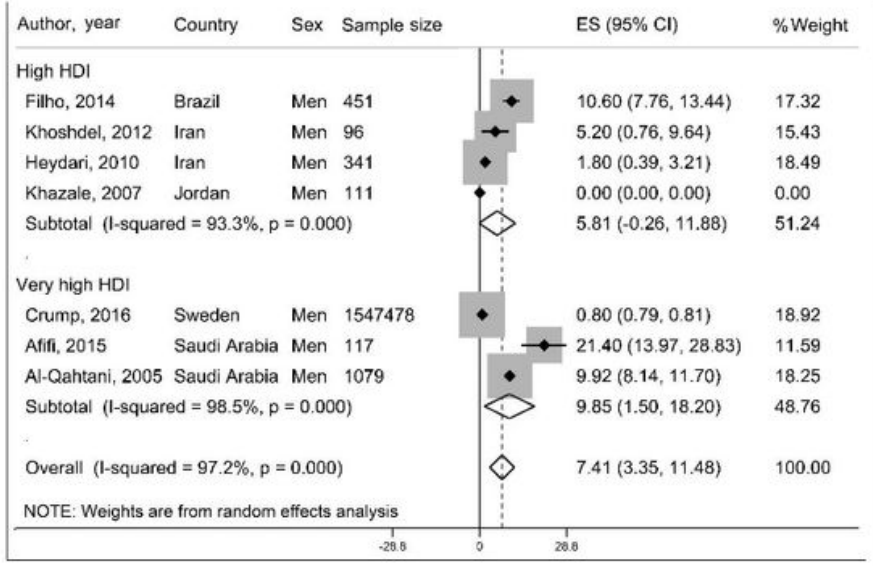

B

\begin{tabular}{|c|c|c|c|c|c|c|}
\hline Author, year & Country & Sex & Sample size & & ES $(95 \% \mathrm{Cl})$ & $\%$ Weight \\
\hline \multicolumn{7}{|l|}{ Low HDI } \\
\hline Lindman, 2017 & Guinea-Bissau & Both & 1104 & $\bullet$ & $4.10(2.93,5.27)$ & 11.02 \\
\hline Tesfaye, 2016 & Ethiopia & Both & 936 & $\bullet$ & $5.00(3.60,6.40)$ & 10.97 \\
\hline \multicolumn{4}{|c|}{ Subtotal (l-squared $=0.0 \%, p=0.333$ ) } & 1 & $4.47(3.57,5.37)$ & 21.98 \\
\hline \multicolumn{7}{|c|}{. } \\
\hline \multicolumn{7}{|l|}{ Medium HDI } \\
\hline Masih, 2019 & India & Men & 155 & $\rightarrow-$ & $31.60(24.28,38.92)$ & 7.79 \\
\hline Phiri, 2017 & Zambia & Both & 148 & $\leftrightarrow 1$ & $9.10(4.47,13.73)$ & 9.50 \\
\hline Kumar, 2013 & India & Both & 1817 & & $15.00(13.36,16.64)$ & 10.90 \\
\hline Thayyil, 2012 & India & Men & 823 & - & $7.00(5.26,8.74)$ & 10.87 \\
\hline Tharkar, 2008 & India & Men & 318 & $\rightarrow$ & $32.10(26.97,37.23)$ & 9.20 \\
\hline Kumar, 2008 & India & Men & 2160 & 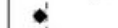 & $11.50(10.15,12.85)$ & 10.98 \\
\hline \multicolumn{4}{|c|}{ Subtotal (1-squared $=96.2 \%, p=0.000)$} & & $16.83(11.81 .21 .85)$ & 59.24 \\
\hline \multicolumn{7}{|l|}{. } \\
\hline \multicolumn{7}{|l|}{ Very high HDI } \\
\hline Moline, 2016 & USA & Both & 2497 & 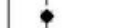 & $14.00(12.64,15.36)$ & 10.97 \\
\hline Yoo, 2013 & USA & Men & 106 & + & $17.90(10.60,25.20)$ & 7.80 \\
\hline \multicolumn{4}{|c|}{ Subtotal (I-squared $=5.7 \%, p=0.303$ ) } & 0 & $14.23(12.42,16.05)$ & 18.78 \\
\hline \multicolumn{7}{|l|}{. } \\
\hline \multicolumn{4}{|c|}{ Overall (1-squared $=97.3 \%, p=0.000$ ) } & $\diamond$ & $13.87(10.14,17.60)$ & 100.00 \\
\hline \multicolumn{7}{|c|}{ NOTE: Weights are from random effects analysis } \\
\hline & & & -38.9 & 0 & & \\
\hline
\end{tabular}

\section{Figure 2}

The prevalence of diabetes among the military personnel $(A)$ and police officers $(B)$ stratified by human development index (HDI).

A

\begin{tabular}{|c|c|c|c|c|c|}
\hline Author & Country & Sex & Sample size & ES (95\% Cl) & $\%$ Weight \\
\hline Khoshdel, 2012 & Iran & Men & 96 & $4.20(0.19,8.21)$ & 33.17 \\
\hline Heydari, 2010 & Iran & Men & 341 & $8.50(5.54,11.46)$ & 44.42 \\
\hline Khazale, 2007 & Jordan & Men & 111 & $9.60(4.12,15.08)$ & 22.40 \\
\hline \multicolumn{4}{|c|}{ Overall (I-squared $=44.3 \%, p=0.166$ ) } & $7.32(4.22,10.42)$ & 100.00 \\
\hline \multicolumn{4}{|c|}{ NOTE: Woights are from randon effects anaysis } & & \\
\hline
\end{tabular}

B

\begin{tabular}{|c|c|c|c|c|c|}
\hline Author & Country & Sex & Sample size & ES $(95 \% \mathrm{Cl})$ & $\%$ Weight \\
\hline \multicolumn{6}{|l|}{ Low HDI } \\
\hline Lindman, 2017 & Guinea-Bissau & Both & 1104 & $4.20(3.02,5.38)$ & 21.35 \\
\hline Tesfaye, 2016 & Ethiopia & Both & 936 & $8.00(6.26,9.74)$ & 17.14 \\
\hline \multicolumn{4}{|c|}{ Subtotal (I-squared $=92.0 \%, p=0.000$ ) } & $6.04(2.32,9.77)$ & 38.49 \\
\hline . & & & & & \\
\hline \multicolumn{6}{|l|}{ Medium HDI } \\
\hline Kumar, 2013 & India & Both & 1817 & $6.80(5.64,7.96)$ & 21.55 \\
\hline Thayyil, 2012 & India & Men & 823 & $6.70(4.99,8.41)$ & 17.36 \\
\hline Kumar, 2008 & India & Men & 2160 & $6.20(5.18,7.22)$ & 22.60 \\
\hline \multicolumn{4}{|c|}{ Subtotal (I-squared $=0.0 \%, p=0.724$ ) } & $6.50(5.80,7.20)$ & 61.51 \\
\hline \multicolumn{6}{|l|}{. } \\
\hline \multicolumn{4}{|c|}{ Overall $(1-$ squared $=75.6 \%, p=0.003$ ) } & $6.30(5.11,7.49)$ & 100.00 \\
\hline \multicolumn{6}{|c|}{ NOTE: Weights are from random efflects analysis } \\
\hline & & & $\begin{array}{c}1 \\
-9.77\end{array}$ & 77 & \\
\hline
\end{tabular}

\section{Figure 3}

The prevalence of prediabetes among the military personnel $(A)$ and police officers $(B)$ stratified by human development index (HDI). 


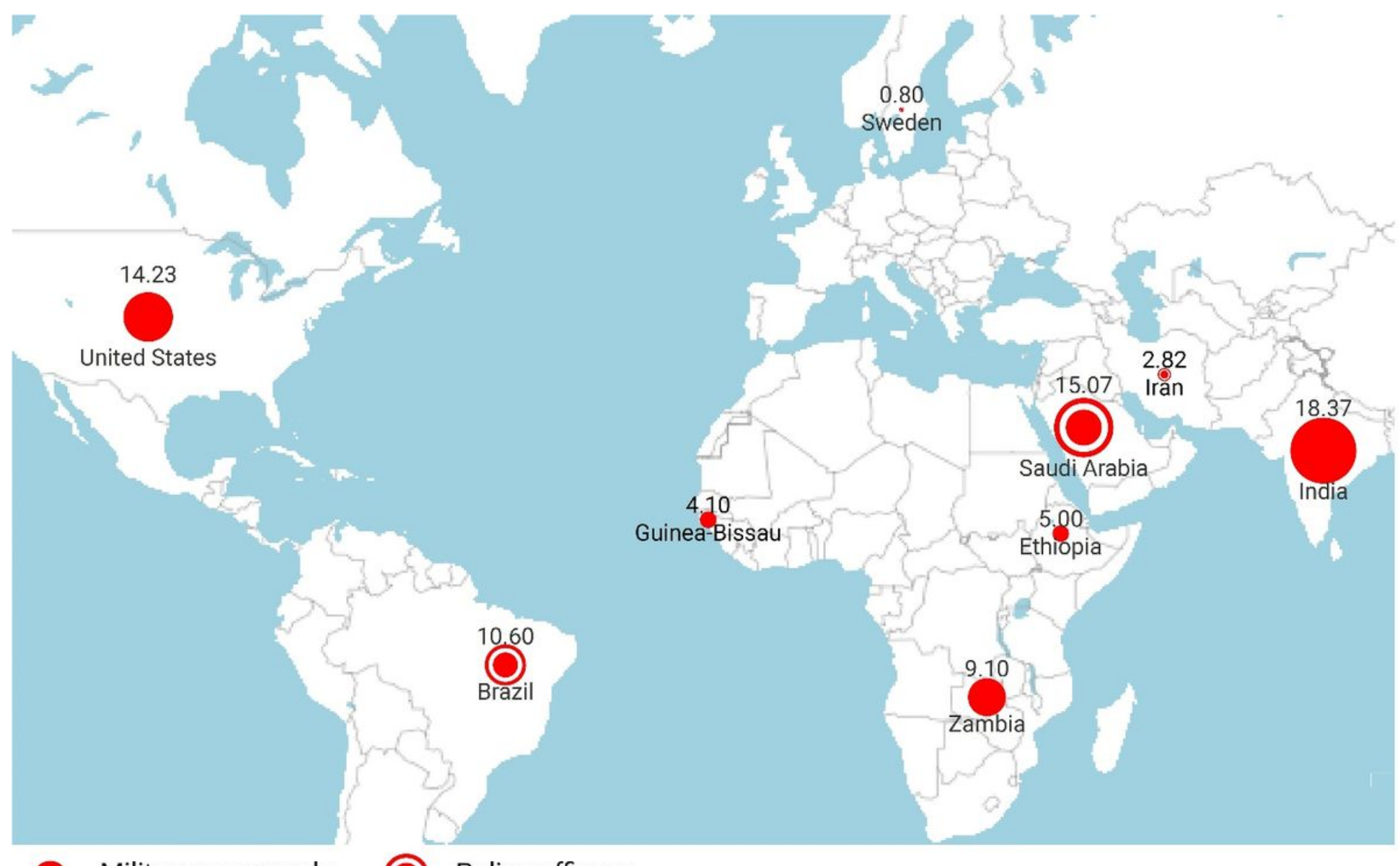

Military personnels Police officers

Figure 4

Prevalence of diabetes (top) and prediabetes (bottom) among military personnel and police officers. 

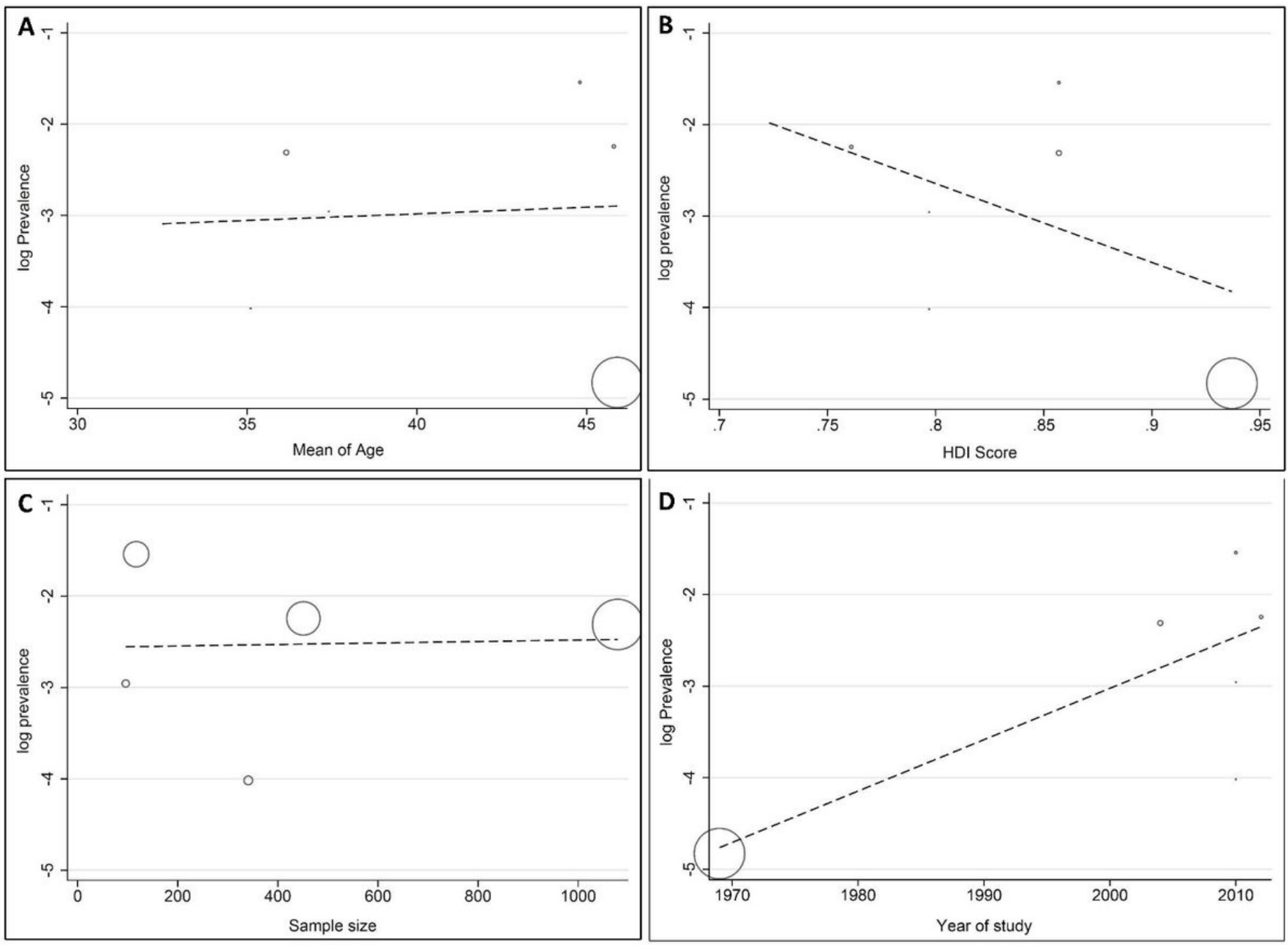

Figure 5

The association between the prevalence of diabetes and mean age of participants (A), Human Development Index score (B), sample size (C), and publication year of study (D) among military personnel. 

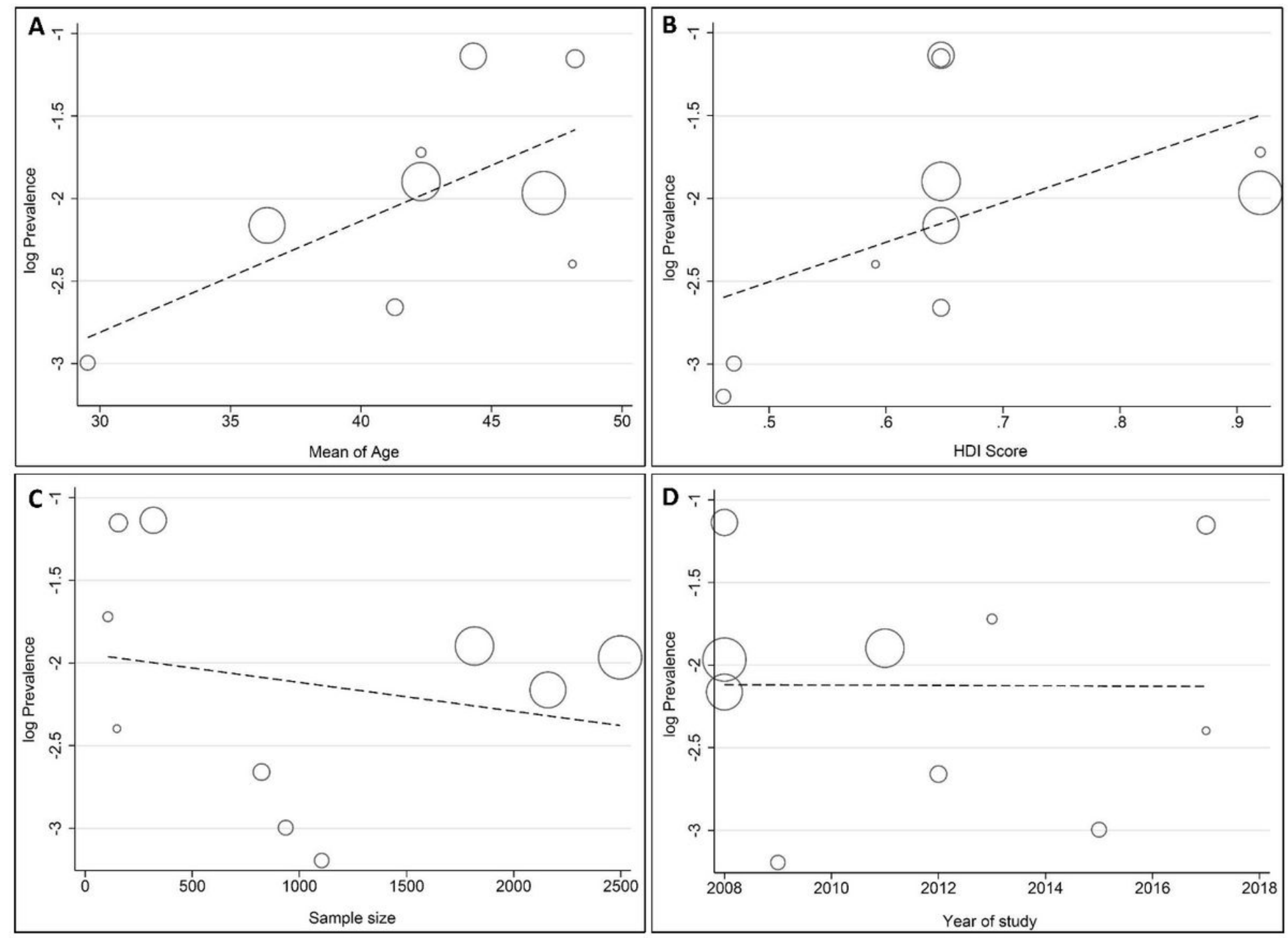

Figure 6

The association between the prevalence of diabetes and mean age of participants (A), Human Development Index score (B), sample size (C), and publication year of study (D) among police officers.

\section{Supplementary Files}

This is a list of supplementary files associated with this preprint. Click to download.

- Appendix2.docx

- PRISMA2009checklist.doc

- Appendix1.docx 